\title{
EDIBLE FILM DARI KARAGENAN DAN MINYAK CENGKEH SEBAGAI ANTIMIKROBA PADA IKAN SEGAR
}

\author{
Edible Film From Carrageenan And Clove Oil As Antimicrobial In Fresh Fish \\ Ali Jaja ${ }^{11}$, R. Marwita Sari Putri ${ }^{\left.{ }^{*}\right)}$, Jumsurizal ${ }^{1)}$ \\ ${ }^{1)}$ Program Studi Teknologi Hasil Perikanan, Fakultas IImu Kelautan dan Perikanan, \\ Universitas Maritim Raja Ali Haji, Tanjungpinang, 2911, Indonesia \\ *korespondensi: wita@umrah.ac.id
}

Diterima : 13 Februari 2021; Disetujui : 27 April 2021

\begin{abstract}
Edible film is a type of packagingthat is both effective and safe. Edible film maked using natural ingredients such as carrageenan. Clove oil addetional to enhance its antimicrobial function. This study puposed to determine the effect of using carrageenan and clove oil concentrations in the organoleptic and ALT test. The design used was used was CRD with test parameter namely thikness tset, elongation, tensile strenght, organoleptic quality obcervation and ALT. Thikness test result 0.02-0.13 $\mathrm{mm}$, elongation 1.027-1.117\%, tensile strength 0.088-0.095 MPa, the best organoleptic is A2 on

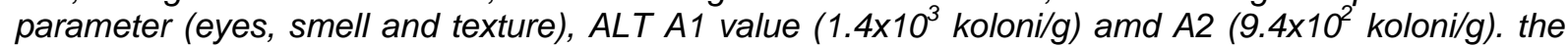
reduction of carrageenan and additional of clove oil resulted in increased thikness and tensile strenht, while decreasing elongation. Based on the organoleptic test, the best the best treatment was edible film A2. ALT A1 and A2 test result do not exceed the threshold.
\end{abstract}

Keywords: $A L T$, carrageenan, clove oil, edible film, fresh fish

\begin{abstract}
ABSTRAK
Edible film merupakan jenis kemasan yang prosfektif dan aman. Edible film dibuat dengan menggunakan bahan alami seperti karagenan. Minyak cengkeh ditambahkan untuk meningkatkan fungsi sebagai antimikroba. Penelitian bertujuan untuk melihat pengaruh penggunaan konsentrasi karagenan dan minyak cengkeh pada uji organoleptik dan ALT. Rancangan yang digunakan yaitu RAL dengan parameter uji yaitu uji ketebalan, elongasi, kuat tarik, pengamatan mutu organoleptik dan ALT. Hasil uji ketebalan 0,02-0,13 mm, elongasi $1,027-1,117 \%$, kuat tarik $0,088-0,095 \mathrm{MPa}$, organoleptik terbaik yaitu A2 pada parameter (mata, bau dan tekstur), nilai ALT A1 $\left(1,4 \times 10^{3} \mathrm{koloni} / \mathrm{g}\right.$ ) dan A2 $\left(9,4 \times 10^{2}\right.$ koloni/g). Pengurangan karagenan dan penambahan minyak cengkeh mengakibatkan ketebalan dan kuat tarik meingkat, sementara elongasi menurun. Berdasarkan uji organoleptik, perlakuan terbaik yaitu edible film A2. Hasil uji ALT A1 dan A2 tidak melebihi ambang batas.
\end{abstract}

Kata kunci: ALT, edible film, ikan segar, minyak cengkeh, karagenan

\section{PENDAHULUAN}

Plastik merupakan salah satu kemasan yang biasa digunakan untuk mengemas bahan baku maupun produk. Pada dasarnya kemasan plastik dapat memberikan efek negatif pada produk maupun bahan makanan, karena plastik mengandung bahan kimia berbahaya dan bersifat nonbiodegradable, sehingga dapat merusak lingkungan. Dari pada itu agar lingkungan tetap terjaga perlu dianggap perlu untuk mengurangi kemasan plastik menjadi edible film.

Sifat dari kemasan ini dapat langsung dikonsumsi serta dapat memberikan perlindungan langsung pada produk ketika kemasan pertama dibuka, (Sutono dan Pranoto 2013). Fungsi edible film sangat tergantung pada formulasi bahan pembuatnya dan kondisi bahan yang dilapisi. Oleh sebab itu masih diperlukan penelitian 
lebih lanjut untuk menghasilkan lembaran film yang baik, karena biasanya film yang dihasilkan masih mempunyai nilai permeabilitas terhadap uap air dan gas yang besar. Nilai permeabilitas sangat dipengaruhi oleh faktor-faktor sifat kimia polimer, struktur dasar polimer dan komponen penyusunnya, (Supeni 2012). Edible film yang dihasilkan dari polisakarida memiliki struktur yang kompak dan kelarutannya yang rendah, tetapi sifat film yang dihasilkan adalah rapuh, (Wattimena et al. 2016).

Gliserol berfungsi sebagai plasticizer untuk meningkatkan karakteristik film. Gliserol adalah bahan yang ditambahkan ke dalam bahan pembentuk edible film. Penggunaanya dapat meningkatkan fleksibelitas, menurunkan gaya intermoelekuler sepanjang rantai polimernya, sehingga film akan lentur apabila dibengkokkan, (Prasetyo dan Laia 2018). Minyak cengkeh memiliki kandungan eugenol. Senyawa eugenol dan turunannya yang bersifat antioksidan maupun antimikrobadapat digunakan sebagai bahan baku edible film dengan bahan pembentuk lainnya berupa polisakarida, (Towaha 2012). Penggunaan minyak cengkeh pada kemasan edible film dikarenakan minyak cengkeh merupakan salah satu jenis rempahrempah yang tergolong ke dalam minyak atsiri (minyak kayu manis, daun serai, cengkeh dan bawang putih) telah diteliti aktivitas antibakteri, (Paliling et al. 2016).

Kemasan edible film antimikroba akan diaplikasikan pada bahan baku ikan segar, yaitu ikan tamban (Sardinella lemuru). Pengemasan dilakukan untuk mengetahui tingkat kerusakan pada Ikan yang dilihat dari pengaruh penggunaan edible film antimikroba dengan penambahan minyak cengkeh sebagai antimikroba yang diharapkan mampu menghambat mikroorganisme patogen pada penyimpanan bahan baku ikan segar.

\section{METODE PENELITIAN}

\section{Bahan dan Alat}

Bahan yang digunakan yaitu; tepung karagenan, minyak cengkeh, gliserol, PCA dan akuades. Sedangkan alat yang digunakan diantaranya; timbangan analitik, oven, inkubator, hot plate/magnetic stirrer, cetakan plat kaca 20×25 cm, gelas ukur, beaker glass, spatula dan pemberat $1 \mathrm{~kg}$.

\section{Prosedur Penelitian}

Penelitian dilakukan dengan beberapa tahap, yaitu pembuatan edible film, uji katakteristik edible film, uji organoleptik dan perhitungan mikrobiologis, berikut formulasi edile film karagenan dan minyak cengkeh pada Tabel 1.

Tabel 1. Formulasi bahan pembuatan edible film

\begin{tabular}{lrcc}
\hline \multicolumn{1}{c}{ Bahan } & \multicolumn{3}{c}{ Perlakuan } \\
\cline { 2 - 4 } & A1 & A2 & A3 \\
\hline Karagenan $(\mathrm{g})$ & 2,0 & 1,5 & 1,0 \\
Minyak cengkeh $(\mathrm{mL})$ & 0 & 0,1 & 0,2 \\
Gliserol $(\mathrm{mL})$ & 5,0 & 5,0 & 5,0 \\
Akuades $(\mathrm{mL})$ & 93 & 93,4 & 93,8 \\
\hline
\end{tabular}

Sumber: (Modifikasi Fardhiyanti et al. 2015)

\section{Pembuatan Edible Film}

Proses pembuatan edible film antimikroba dengan memodifikasi metode Sepeni (2012), Pembuatan edible film dilakukan menurut Supeni (2015), dengan memodifikasi penambahan minyak cengkeh adalah sebagai berikut: larutan dibuat dengan konsentrasi karagenan sesuai perlakuan 1, 1,5 dan 2 (gram) dengan cara, yaitu setiap perlakuan tepung karagenan dimasukkan ke dalam beaker glass dan ditambahakan aquades hingga mencapai $100 \mathrm{~mL}$ volume larutan, kemudian diaduk dengan magnetik stirer dan dipanaskan diatas hot plate hingga suhu mencapai 90 ${ }^{\circ} \mathrm{C}$. Setelah itu gliserol dimasukkan sebanyak $5 \mathrm{~mL}$ serta menambahkan minyak cengkeh 0,1 dan $0,2(\mathrm{~mL})$, sambil terus diaduk dan dipanaskan selama 15 menit hingga larutan homogen. 
Proses pencetakan lembaran edible film berdasarkan metode Rusli et al. (2017), yang dimodifikasi sebagai berikut; larutan edible film dituangkan ke dalam cetakan plat kaca, setelah larutan dimasukkan pada plat kaca, kemudian dibiarkan hingga 2 jam pada suhu ruang. Selanjutnya proses pengeringan di dalam oven pada suhu $60^{\circ} \mathrm{C}$, (Caroline dan Pratiwi 2017) selama 24 jam agar lembaran edible film terbentuk dan mengering dengan sempurna. Lembaran edible film kemudian dilepaskan dan dibiarkan selama 2 jam hingga mencapai suhu ruang (Fhardiyanti et al. 2015).

\section{Analisis karakteristik Edible Film}

Parameter uji pada penelitian ini meliputi; uji krakteristik (Ketebalan film, waktu kelarutan, elongasi, kuat tarik dan ketahanan film terhadap air).

\section{Ketebalan}

Ketebalan diukur dengan memodifikasi metode, (Muin et al. 2017).

\section{Elongasi dan kuat tarik}

Analisis elongitas dan kuat tarik menggunakan metode, (Muin et al. 2017). Kuat tarik dapat dihitung dengan rumus:

Kuat tarik $(\mathrm{MPa})=\frac{\text { Gaya }(\mathrm{N})}{\text { Luas sampel }\left(\mathrm{mm}^{2}\right)}$

Presentasi elongasi dihitung dengan rumus:

Elongasi $(\%)=\frac{\text { Panjang setelah putus }}{\text { Panjang awal }} \times 100 \%$

\section{Pengamatan mutu organoleptik}

Pengamatan mutu organoleptik dilakukan dengan score sheet, (BSN 2013). 15 orang panelis semi terlatih. Perlakuan yang digunakan yaitu A1 (edible film karagenan $2 \%$ dan minyak cengkeh $0 \%$ ), A2 (edible film karagenan $1,5 \%$ dan minyak cengkeh 0,1\%) dan A3 (edible film karagenan $1 \%$ dan minyak cengkeh $0,2 \%$ ) dilakukan pada ikan sardin segar selama 5 jam dan diamati per-jam.

\section{Uji Angka Lempeng Total (ALT)}

Uji ALT dilakukan pada perlakuan A1 dan A2 hasil terbaik dari uji mutu organoleptik menggunakan ikan tamban, setelah didapati hasil perhitungan total bakteri tersebut, kemudian dibandingkan dengan standar mutu ikan segar yang ditetapkan oleh SNI, (BSN 2015).

\section{Analisis data}

Data hasil akan diolah menggunakan SPSS versi 23 dengan Rancangan Acak Lengkap (RAL), tiga kali pengulangan untuk setiap perlakuan. Pada uji karakteristik esible film diuji dengan metode analisis sidik ragam (ANOVA) setelah terdapat perbedaan, selanjutnya akan di analisis dengan uji lanjut BNT (Beda Nyata terkecil). Hasil uji organoleptik akan diuji menggunakan uji kruskal-wallis. Hasil uji Angka Lempeng Total (ALT) ikan Tamban (Sardinella lemuru) akan dibandingkan dengan nilai ALT sesuai Standar Nasional Indonesia (SNI) (2729.2013).

\section{HASIL DAN PEMBAHASAN}

\section{Karakteristik film}

Pengujian pada karakteristik edible film dari karagenan dan minyak cengkeh sebagai antimikroba pada ikan segar, yaitu analisis ketebalan, kuat tarik dan elongitas edible film.

\section{Ketebalan Edible Film}

Hasil uji ketebalan edible film antimikroba menunjukkan bahwa edible film 0,02-0,13 mm. Gambar 1, menunjukkan bahwa semakin rendah konsentrasi karagenan yang dimasukkan ke dalam larutan edible film, maka tingkat ketebalan film akan menurun. Hal tersebut dapat terjadi karena semakin banyaknya bobot 
dari karagenan akan meningkatkan total padatan dalam larutan edible film.

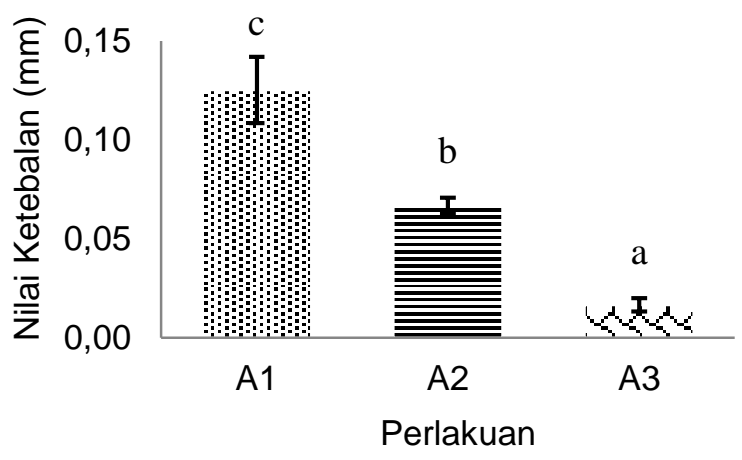

Keterangan:

A1: Karagenan $2 \mathrm{~g}$ dan minyak cengkeh $0 \mathrm{~mL}$ A2: Karagenan 1,5 g dan minyak cengkeh $0,1 \mathrm{~mL}$ A3: Karagenan $1 \mathrm{~g}$ dan minyak cengkeh $0,2 \mathrm{~mL}$ Huruf yang berbeda menunjukkan perbedaan yang nyata

\section{Gambar 1. Nilai Ketebalan Edible Film Antimikroba}

Hasil analisis sidik ragam pada ketebalan film $(\mathrm{P}<0,05)$, menunjukkan bahwa, terdapat pengaruh yang signifikan pada perlakuan konsentrasi karagenan dan minyak cengkeh terhadap nilai ketebalan edible film. Kemudian dilanjutkan dengan uji lanjut BNT (Beda Nyata terkecil), menunjukkan bahwa perlakuan $A 1$ berbedanyata dengan perlakuan $\mathrm{A} 2$ dan $\mathrm{A} 3$. Pada penelitian ini menghasilkan edible film dengan ketebalan 0,02 $\mathrm{mm}$ hingga 0,13 mm masih memenuhi standar JIS (Japanesse Industrial Standart), karena berdasarkan standar tersebut ketebalan yang baik yaitu kurang dari 0,25 mm, (Putri et al. 2019).

\section{Elongasi dan Kuat Tarik}

Pada penelitian ini, nilai elongasi edible film dapat dilihat pada Tabel 2. Hasil uji elongasi berkisar pada 1,027-0,117\%.

Tabel 2. Hasil uji elongasi dan kuat tarik edible film antimikroba

\begin{tabular}{lccc}
\hline Sifat Mekanik & A1 & A2 & A3 \\
\hline Kuat tarik (Mpa) & $0,092 \mathrm{~b}$ & $0,088 \mathrm{a}$ & $0,095 \mathrm{c}$ \\
Elongasi (\%) & $1,067 \mathrm{~b}$ & $1,117 \mathrm{c}$ & $1,027 \mathrm{c}$
\end{tabular}

Keterangan: huruf yang berbeda menunjukkan perbedaan yang nyata
Hasil analisis sidik ragam nilai elongasi $(\mathrm{P}<0,05)$, menunjukkan bahwa terdapat pengaruh dari perlakuan konsentrasi karagenan dan minyak cengkeh terhapat nilai elongasi. Hasil uji BNT (Beda Nyata terkecil) menunjukkan bahwa perlakuan A1 berbeda nyata dengan perlakuan $\mathrm{A} 2$ dan A3.

Berdasarkan hasil penelitian pada Tabel 2, menunjukkan bahwa seiring dengan bertambahnya volume minyak cengkeh dan berkurangnya bobot karagenan, maka nilai kuat tarik semakin meingkat. Nilai kuat tarik pada penelitian ini berkisar antara 0,088$0,095 \mathrm{MPa}$. Nilai kuat tarik terendah terdapat pada perlakuan A2 yakni sebesar $0,088 \mathrm{MPa}$ dan nilai kuat tarik tertinggi terdapat pada perlakuan $A 3$ yakni sebesar 0,095 MPa.

Berdasarkan hasil analisis sidik ragam $(P<0,05)$, terlihat bahwa terdapat pengaruh konsentrasi karagenan dan minyak cengkeh terhadap nilai kuat tarik edible film..kemudian dilakukan uji lanjut BNT (Beda Nyata terkecil), $\quad(P<0,05)$ menunjukkan bahwa perlakuan $A 1$ berbeda nyata dengan perlakuan $\mathrm{A} 2$ dan $\mathrm{A} 3$.

\section{Mutu Organoleptik}

Menurut Tamuu et al. (2014), mata ikan segar ditandai dengan bentuk bola mata cembung atau relatif datar, sedangkan ikan tidak segar ditandai dengan bola mata cekung dan keruh. Mengacu pada standar mutu ikan segar yang ditetapkan oleh SNI (2729-2013) bahwa kenampakan bola mata ikan tamban hasil perlakuan edible film antimikroba perlakuan A2 masih memenuhi syarat milai mutu organoleptik yakni 7 . Sedangkan mata ikan pada perlakuan A1 dan A2 belum memenuhi persyaratan SNI yakni bola mata agak cekung, kornea keruh dan pupil berwarna keabu-abuan, BSN 2013. Nilai Uji Organoleptik mata ikan tamban dapat dilihat pada Gambar 2a. 

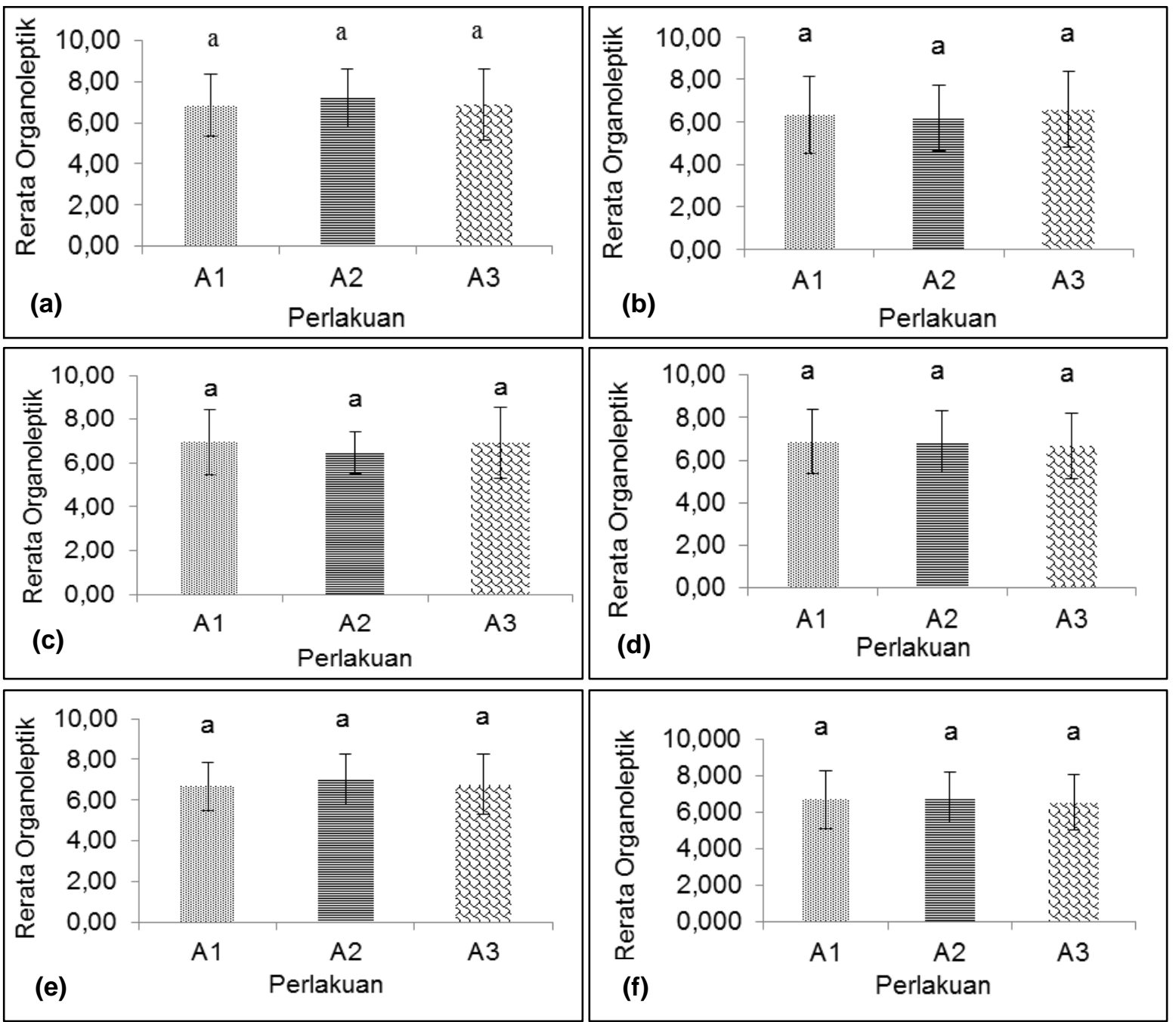

Keterangan:

A1 : Karagenan $2 \mathrm{~g}$ dan Minyak cengkeh $0 \mathrm{~mL}, \mathrm{~A} 2$ : Karagenan 1,5 g dan Minyak cengkeh 0,1 $\mathrm{mL}$, A3 : Karagenan $1 \mathrm{~g}$ dan Minyak cengkeh 0,2 $\mathrm{mL}$, Keterangan: huruf yang berbeda menunjukkan perbedaan yang nyata

Gambar 2. Nilai uji organoleptik (a) mata, (b) insang, (c) lendir, (d) daging, (e) bau, (f) tekstur ikan tamban (Sardinella lemuru)

Hasil uji kruskal-wallis pada nilai mutu mata ikan tamban $(P>0,05)$ menunjukkan nilai bahwa tidak terdapat perbedaan antara perlakuan penggunaan edible film pada mata ikan tamban.

Nilai organoleptik insang ikan tamban pada Gambar 2b, terlihat mengalami peningkatan seiring dengan penambahan konsentrasi minyak cengkeh $0,2 \mathrm{~mL}$ pada edible film yang digunakan, namun pada penambahan minyak cengekeh $0,1 \mathrm{~mL}$ mengalami penurunan. Berdasarkan hasil pengamatan mutu organoleptik nilai mutu tertinggi pada perlakuan A3 yakni. Nilai terendah terdapat pada perlakuan $\mathrm{A} 2$ yaitu 6,18

Hasil uji kruskal wallis nilai mutu organoleptik (P>0,05), dapat disimpulkan bahwa tidak terdapat perbedaan penggunaan edible film antimikroba selama pengamatan masa nilai mutu organoleptik insang ikan tamban.

Kenampakan mata ikan tamban pada perlakuan A1, A2 dan A3 memiliki nilai mutu 
organoleptik sebesar 6,18-6,59. Nilai tersebut termasuk ke dalam kategori kurang segar. Hal tersebut menenjukkan bahwa nilai mutu insang ikan tamban yang memperlihatkan ikan dalam kategori kurang segar yang menunjukkan ciri-ciri insang yakni warna insang merah muda atau coklat muda dengan lendir agak keruh. Sementara itu untuk nilai ikan segar yaitu minimal 7 yang ditandai dengan ciri-ciri warna insang merah muda, atau coklat muda dengan sedikit lendir agak keruh, (BSN, 2013).

Nilai uji organoleptik lendir ikan tamban (Gambar 2c) menunjukkan tertinggi terdapat pada perlakuan A1 6,95 dan nilai mutu organoleptik lendir ikan terendah terdapat pada perlakuan A2 yakni 6,47. Hasil uji kruskal-wallis pada mutu organoleptik kenampakan lendir ikan menunjukkan nilai $(P>0,05)$, dapat disimpulkan bahwa tidak terdapat perbedaan pada penggunaan edible film antimikroba perlakuan $\mathrm{A} 1, \mathrm{~A} 2$ dan A3.

Berdasarkan dari penilaian mutu organoleptik daging ikan tamban (Gambar 2d) pada perlakuan A1 dan A2 memiliki ciriciri sayatan daging kurang cemerlang dan jaringan daging sedikit kurang kuat. Pada perlakuan A3 menunjukkan ciri-ciri yang sama yakni sayatan daging kurang cemerlang dan jaringan daging sedikit kurang kuat, (BSN 2013). Hasil uji kruskalwallis pada mutu daging ikan tamban $(P>0,05)$, menunjukkan bahwa bahwa tidak terdapat perbedaan yang signifikan antara perlakuan konsentrasi yang diberikan untuk perlakuan A1, A2 dan A3.

Nilai organoleptik bau ikan tamban yang ditunjukkan pada Gambar 2e, nilai tertinggi terdapat pada perlakuan A2 yakni 7,01 dan nilai terendah terdapat pada perlakuan $A 1$ yakni 6,68. Hasil analisis kruskal wallis nilai dari bau ikan tamban $(P>0,05)$, dapat disimpukan bahwa tidak terdapatperbedaan yang signifikan pada perlakuan A1, A2 dan A3. Hasil penelitian menunjukkan bahwa nilai mutu organoleptik berkisat antara 6,68-
7,01. Dimana nilai mutu organoleptik meningkat seiring dengan bertambahnya volume minyak cengkeh. Hal tersebut menandakan bahwa pada perlakuan $\mathrm{A} 1$ dan A2 dengan penambahan minyak cengkeh 0,1 dan $0,2 \mathrm{~mL}$ mampu untuk mempertahankan nilai mutu pada bau ikan tamban.

Nilai mutu organoleptik tekstur ikan tamban (Gambar 2f) menunjukkan bahwa pada perlakuan A1 tanpa minyak cengkeh dan perlakuan A3 dengan penambahan minyak cengkeh $0,2 \mathrm{~mL}$ mengalami penurunan, namun pada perlakuan A2 dengan penambahan minyak cengkeh 0,1 $\mathrm{mL}$ meningkat. Nilai mutu organoleptik nilai organoleptik tertinggi terdapat pada perlakuan A2 yakni 6,80 dan nilai organoleptik terendah terdapat pada perlakuan A3 yakni 6,52. Hasil analisis kruskall wallis nilai rata-rata dari pengamatan terhadap tekstur ikan tamban $(P>0,05)$, nilai tersebut menunjukkan bahwa tidak terdapat perbedaan pada perlakuan $A 1, A 2$ dan $A 3$.

\section{Angka Lempeng Total (ALT)}

Penentuan total mikroba pada penelitian ini dilakukan untuk melihat pengaruh penggunaan edible film antimikroba dari karagenan dan minyak cengkeh pada ikan segar. Berikut disajikan perbedaan hasil uji ALT perlakuan A1 tanpa minyak cengkeh dan A2 dengan minyak cengkeh $0,1 \mathrm{~mL}$ pada Tabel 3.

Tabel 3. Angka Lempeng Total (ALT) Ikan Tamban (Sardinella lemuru) Perlakuan A1 dan A2 Selama 5 Jam

\begin{tabular}{ccc}
\hline \multirow{2}{*}{ Perlakuan } & \multicolumn{2}{c}{ Total Mikroba (koloni/g) } \\
\cline { 2 - 3 } & Hasil uji TPC & SNI $^{\star}$ \\
\hline A1 & $1,4 \times 10^{3}$ & $5,0 \times 10^{5}$ \\
A2 & $9,4 \times 10^{2}$ & \\
\hline
\end{tabular}

* SNI 2729:2013

Mikroorganisme yang hidup pada suhu optimum $35^{\circ} \mathrm{C}$ pada perlakuan $\mathrm{A} 1$ dengan total bakteri 1,4 × $10^{3}$ koloni/gram sedangkan 
perlakuan A2 dengan total bakteri 9,4 x 102 koloni/gram.

Perlakuan A1 memiliki nilai yang cukup tinggi dibanding perlakuan A2. Hal tersebut diduga karena edible film perlakuan A1 tanpa kandungan minyak cengkeh, sehingga efektifitas antibakterinya tidak meningkat pada proses penyimpanan bahan baku ikan segar. Hasil uji ALT pada perlakuan A2 memiliki nilai total bakteri yang rendah yaitu $9,4 \times 10^{2}$ koloni/gram dibandingakn dengan perlakuan $A 1$. Hal tersebut dapat terjadi karena pada perlakuan A2 menggunakan edible film dengan penambahan minyak cengkeh $0,1 \mathrm{~mL}$.

Berdasarkan nilai tersebut, penambahan minyak cengkeh diduga dapat meningkatkan efektifitas antibakteri pada kemasan edible film, sehingga edible film perlakuan A2 mampu mempertahankan masa simpan ikan tamban selama 5 jam. Hal tersebut barkaitan dengan penelitian Andriasty et al (2015), yang menyatakan bahwa minyak atsiri mengandung komponen yang dapat menghasilkan antimikroba dalam menghambat pertumbuhan bakteri. Dengan menambahkan senyawa aktif antibakteri ke dalam edible film dapat memberikan keuntungan, yaitu meningkatkan daya simpan. Selain itu juga bersifat sebagai penghalang yang berasal dari edible film yang ditambahkan dengan senyawa aktif antimikroba, (Andriasty et al. 2015).

\section{KESIMPULAN}

Perlakuan penambahan karagenan dan pengurangan volume minyak cengkeh pada formulasi larutan edible film menyebabkan ketebalan dan kuat tarik meningkat, tetapi elongasi menurun. Penggunaan edible film antimikroba mampu untuk mempertahankan lama waktu penyimpanan ikan segar sehingga edible film tersebut baik untuk diterapkan pada kemasan produk pangan. ALT menunjukkan bahwa mikroorganisme yang hidup pada suhu ruang pada perlakuan $\mathrm{A} 1$ dan A2 memenuhi standar mutu ikan segar, namun penggunaan edible film perlakuan A2 memiliki jumlah total bakteri lebih rendah dibandingkan dengan perlakuan A1, sehingga edible film A2 lebih efektif dibandingkan perlakuan $\mathrm{A} 1$.

\section{DAFTAR PUSTAKA}

Andriasty, V., Praseptiangga, D., Utami, R. 2015. Pembuatan Edible Film dari Pektin Kulit Pisang Raja Bulu (Musa saplemtumvar var Paradisiaca baker). Dengan Penambahan Minyak Atsiri Jahe Emprit (Zingiber officinalle var. amarum) dan Aplikasinya Pada Tomat Cherry (Lycopersiconenesculentum var.Cerasiforme). Teknologi Pangan. $4(4) ; 1-7$.

BSN. 2013. Badan Standarisasi Nasional. Tentang Ikan Segar SNI No. 2729:2013. Jakarta.

BSN. 2015. Badan Standarisasi Nasional. Tentang Penentuan Angka Lempeng Total (ALT). Pada Produk Perikanan SNI no. 2332.3:2015. Jakarta.

Caroline, C., Pratiwi, A.R. 2017. Biopreservatif Alami Dalam Pembuatan Edible Film Karagenen Euchema cottonii Dengan Polietilen Glikol Sebagai Plasticizer. Agroteknologi. 11(2): 148-155.

Fardhyanti, D.S., Julianur, S.S. 2015. Karakterisasi Edible Film Berbahan Dasar Ekstrak Karagenan Dari Rumput Laut (Eucheuma cottonii). Jurnal Bahan Alam Terbarukan. 4(2): 48-56.

Muin, R., Anggraini, D., Malau, F. 2017. Karakteristik Fisik dan Antimikroba Edible Film dari Tepung Tapioka dengan Penambahan Gliserol dan 
Kunyit Putih. Jurnal Teknik Kimia. 23(3): 191-198.

Prasetyo, H.A., Laia, F. 2018. Pemanfaatan Gliserol dan Pati Sagu Sebagai edible coating Pada Penyimpanan Jeruk Siam Madu (Citrus nobilis). Jurnal Agroteknosains. 2(1): 158-168.

Putri, R.D.A., Sulistyowati, D., Ardhiani, T. 2019. Analisis Penambahan Carboxymethyl Cellulose terhadap Edible film Pati Ubi Garut Sebagai Pengemas Buah Strawberry. Jurnal Riset Sains dan Teknologi. 3(2): 77-83.

Rusli, A., Metusalach., Salengke., Tahir, M.M. 2017. Karakteristik Edible film Karagenan Dengan Pemblastis Gliserol. PHP. 20(2): 219-229.

Sutono, D., Pranoto, Y. 2013. Ekstrak Rumput Laut (Kappaphycus Alvarezii) Sebagai Cross Linking Agent Pada Pembentukan Edible Film Gelatin Kulit
Ikan Nila Hitam (Oreochromis Mossambicus). Agritech. 33(2): 168.

Supeni, G. 2012. Pengaruh Formulasi Edible Film dari Karagenan terhadap Sifat Mekanik dan Barrier. Kimia Kemasan. 34(3): 281-286.

Tamuu, H., Harmain, R.M., Dali, F.A. 2014. Mutu Organoleptik dan Mikrobiologis Ikan Kembung Segar dengan Penggunaan Larutan Lengkuas Merah. Jurnal IImiah Perikanan dan Kelautan. 2(4): 164-168.

Towaha, J. 2012. Manfaat Eugenol Cengkeh Dalam Berbagai Industri Di Indonesia. Perspektif. 11(2): 79-90.

Wattimena, D., Ega. L., Polnaya, F.J. 2016. Karakteristik Edible Film Pati Sagu Alami dan Pati Sagu Posfat dengan Penambahan Gliserol. Agritech. 36(3): 247-252. 